\title{
ANALYSIS OF STUDENT ERRORS IN COMPLETING MATHEMATICAL PROBLEMS OF CLASS VIII CIRCLE MATERIALS IN SMP 1 WLINGI
}

\author{
Mega Madila Rismawati ${ }^{1)}$ \\ ${ }^{1}$ Program Studi Tadris Matematika, IAIN Tulungagung, \\ E-mail: megamadila@gmail.com
}

\begin{abstract}
This research aims to find out the type of student error in solving the problem of mathematics material in solving the problem of circle story and wide circle in class VIII SMP Negeri 1 Wlingi Blitar.Dalam this research type of research used is descriptive qualitative research. The subject of this study is the class VIII C MPN 1 Wlingi which amounted to 10 students who took the test.Teknik data collection in this study using written tests, interviews and documentation.Keabsahan data is done with reference materials and conduct checks members. Teknik data analysis is done with data reduction stages, data presentation, and verification or drawing conclusions. Students are grouped into three categories namely high-ability students, medium-skilled students and low-ability students. Each category is represented by one student. The results of this study are (1) The type of mistake made by a highly capable subject in solving soa 1 circle story and broad circle is a mistake of fact, error of concept and mistake of principle. (2) Types of moderate-ability students' mistakes are factual errors, concept errors and procedural errors. (3) Types of lowskill students' errors are fact errors, concept errors, procedural errors and principle errors.
\end{abstract}

Keywords: Error analysis, Circuit story and Circle area

\section{PENDAHULUAN}

Matematika merupakan ilmu yang mempunyai peran sentral dalam membentuk pola pikir siswa.Sebab, dalam pembelajaran matematika siswa dibekali dengan berbagai kemampuan diantaranya kemampuan berpikir logis, sistematis, analitis, serta kemampuan menggunakan matematika dalam pemecahan masalah.Pemecahan masalah merupakan bagian yang sangat penting dalam pelajaran matematika (Marlina, 2013).Seperti yang tercantum dalam kurikulum tingkat satuan pendidikan (KTSP) bahwa tujuan pembelajaran matematika adalah memecahkan masalah yang meliputi kemampuan memahami masalah, merancang model matematika, menyelesaikan model dan menafsirkan solusi yang diperoleh (Depdiknas, 2016).

Pendapat Cockroft dalam Ardiyanti (2014) menyatakan bahwa matematika perlu diajarkan kepada siswa karena selalu digunakan dalam segi kehidupan, semua membutuhkan keterampilan matematika dan matematika dapat meningkatkan kemampuan berpikir logis. Hal ini berarti bahwa dalam pembelajaran matematika, seharusnya siswa dapat menggunakan pola pikir matematika dalam kehidupan sehari-hari.Upaya yang dapat dilakukan untuk mencapai tujuan pembelajaran matematika satu diantaranya adalah dengan meyajikan soal-soal cerita. Ardiyanti (2014) menyatakan bahwa satu diantara 
usaha untuk meningkatkan prestasi belajar matematika siswa adalah dengan meningkatkan kemampuan siswa dalam menyelesaikan soal cerita.

Satu diantara pokok bahasan yang sering dianggap sulit oleh siswa dalam pembelajaran matematika adalah materi geometri.Satu diantara materi geometri yang erat kaitannya dengan kehidupan sehari-hari adalah materi keliling dan luas lingkaran.Sehingga, biasanya dalam pembelajaran matematika, materi ini disajikan dalam bentuk soal cerita.Namun, pada kenyataannya siswa masih mengalami kesulitan ketika menghadapi soal cerita keliling dan luas lingkaran.Nuroniah (2013) menyatakan bahwa kesulitan peserta didik dalam mempelajari matematika khususnya geometri terutama pada materi pokok lingkaran.Hal ini menimbulkan terjadinya berbagai kesalahan dalam penyelesaiannya.

Berdasarkan informasi yang diperoleh dari guru dan hasil tes kemampuan siswa dapat disimpulkan bahwa siswa mengalami kesulitan dalam menyelesaikan soal cerita sehingga menyebabkan terjadinya kesalahan.Kesalahan siswa dalam menyelesaikan soal cerita dapat diminimalisir dengan memberikan penanganan yang tepat.Upaya yang dapat dilakukan untuk meminimalisir kesalahan siswa adalah menelusuri kelemahan-kelemahan siswa.Hal ini bertujuan untuk memudahkan guru dalam membuat strategi pembelajaran yang tepat.Kesalahan siswa dapat terungkap dengan melakukan analisis secara mendalam untuk memperoleh gambaran tentang jenis-jenis kesalahan yang dilakukan siswa.Peneliti melakukan penelusuran terhadap jenis-jenis kesalahan fakta, kesalahan konsep, kesalahan prinsip dan kesalahan prosedur.

Beberapa penelitian yang relevan dengan penelitian ini yaitu: (Kurnia,2014) menyimpulkan bahwa kesalahan yang dilakukan siswa dalam menyelesaikan soal cerita yakni: kesalahan memahami soal, kesalahan membuat model matematika, kesalahan melakukan perhitungan, dan menarik kesimpulan. (Nuroniah,2013) menyimpulkan bahwa kesalahan yang dilakukan siswa dalam menyelesaikan soal cerita lingkaran adalah kesalahan data tidak tepat, kesalahan prosedur tidak tepat, dan kesalahan hirarkis keterampilan. (Hidayat,2013) menyimpulkan bahwa kesalahan yang dilakukan siswa yakni kesalahan fakta, kesalahan konsep, kesalahan prinsip dan kesalahan operasi. Tujuan penelitian ini adalah untuk mendeskripsikan jenis-jenis dan faktor penyebab terjadinya kesalahan siswa dalam menyelesaikan soal cerita keliling dan luas lingkaran di kelas VIII C SMPN 1 Wlingi.

Dari beberapa indikasi kesalahan yang ada, dapat diketahui tipe kesalahan siswa ditinjau dari gaya kognitif yang siswa miliki. Hal-hal yang menjadi indikator kesalahan siswa ditinjau dari gaya kognitif antara lain kesalahan fakta, kesalahan konsep, kesalahanoperasi,dankesalahanprinsip.

1. Kesalahanfakta

Fakta dalam matematika berupa konvensi-konvensi yang diungkap dengan simbol tertentu.Kesalahan fakta adalah kesalahan siswa dalam memahami konvensikonvensi (kesepakatan) matematika yang diungkap dengan simbol atau permisalan tertentu. Jadi, fakta dalam matematika dapat berupa simbol, lambang, tanda, atau notasi.Berikut contoh kesalahan fakta: 
a. Siswa salah memahami panjang $r$ tidak sama dengan panjang busur. Terjadinya kesalahan ini disebabkan siswa belum memahami perbedaan antara panjang busur dengan panjang jarijari.

b. Siswa tidak mencantumkan satuan dari luas lingkaran pada akhir operasi hitung. Hal ini disebabkan karena siswa belum benarbenarmemahami matematika

2. Kesalahankonsep

Konsep adalah ide abstrak yang digunakan untuk menggolongkan atau mengklasifikasikan sekumpulan obyek.Kesalahan konsep merupakan kesalahan-kesalahan yang dilakukan oleh siswa dalam menguasai konsepkonsep tertentu.Misalnya :

a. Siswa tidak menyebutkan semua jawaban yang terdapat dalam soal. Hal tersebut diakrenakan siswa kurang memahami konsep darijuring.

b. Kesalahan operasi

Operasi adalah suatu pengerjaan hitung aljabar dan pengerjaan lain. Operasi seringkali disebut skill apabila menekankan pada aspek keterampilannya. Jadi, skill adalah kemampuan penguasaan prosedur, cara kerja atau aturan yang digunakan untuk mengerjakan soal matematika secara cepat dan tepat.Contohnya :

Siswa tidak melanjutkan operasi untuk menemukan jari-jari lingkaran. Penyebabnya ialah siswa masih bingung untuk menyelesaikan operasi tersebut.

c. Kesalahanprinsip

Prinsip adalah obyek matematika yang rumit.Prinsip dapat terdiri dari beberapa fakta, beberapa konsep yang dikaitkan oleh suatu relasi ataupun operasi.Secara sederhana prinsip adalah hubungan antara berbagai obyek dasar matematika.Contohnya :

Siswa belum bisa mengaplikasikan rumus luas lingkaran.

Adapunjenis kesalahan pengolahan data pada penelitian ini dikategorikan menjadi tiga kategori dengan indikator yang disajikan di tabel 1 .

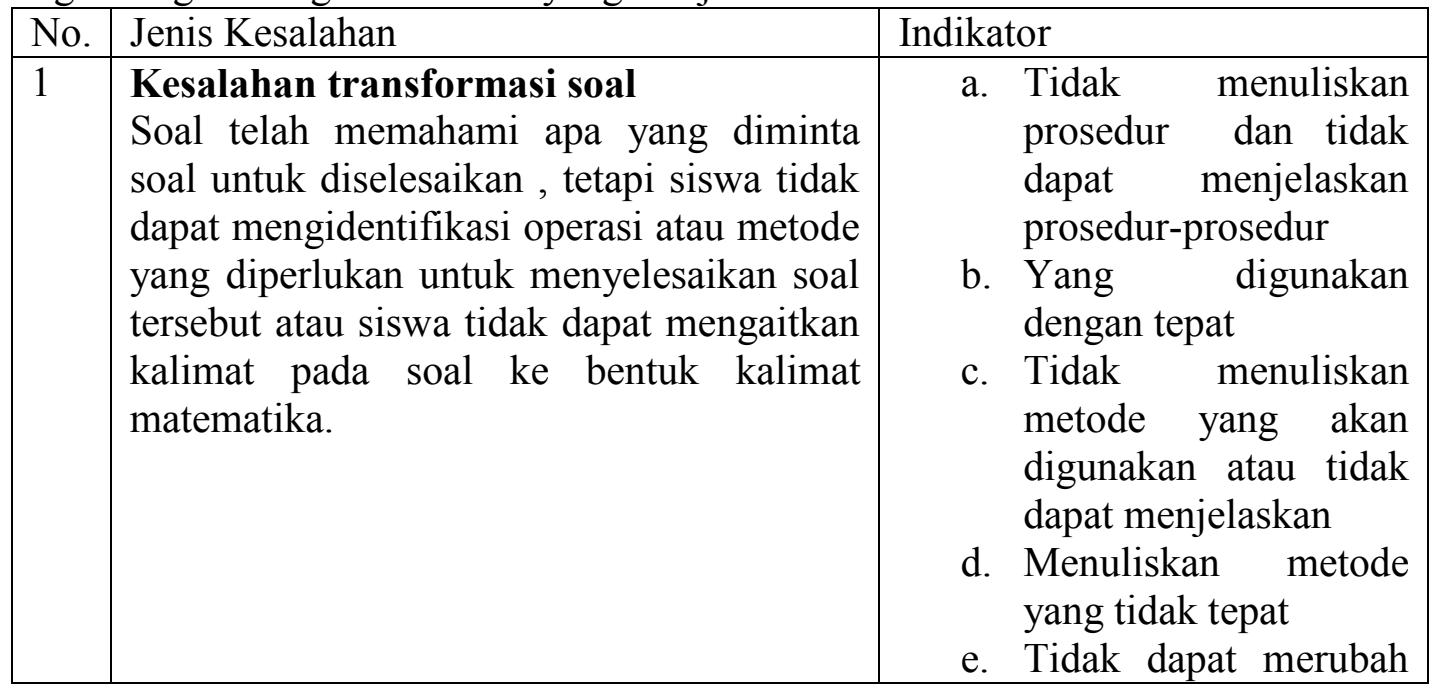




\begin{tabular}{|c|c|c|}
\hline & & $\begin{array}{l}\text { soal ke dalam kalimat } \\
\text { matematika dengan } \\
\text { benar }\end{array}$ \\
\hline 2. & $\begin{array}{l}\text { Kesalahan keterampilan proses } \\
\text { Siswa telah dapat mengidentifikasi operasi } \\
\text { atau metode yang sesuai, tetapi tidak dapat } \\
\text { mengidentifikasi operasi atau metode yang } \\
\text { sesuai, tetapi tidak dapat melakukan } \\
\text { perhitungan dengan benar. }\end{array}$ & $\begin{array}{ll}\text { a. Kesalahan dalam } \\
\text { komputasi } \\
\text { b. Kesalahan konsep } \\
\text { c. Tidak melanjutkan } \\
\text { prosedur penyelesaian } \\
\text { (macet) } \\
\text { d. Tidak menuliskan } \\
\text { rumus dengan tepat } \\
\text { e. Tidak menuliskan dan } \\
\text { menjelaskan tahapan } \\
\text { perhitungan dengan } \\
\text { benar }\end{array}$ \\
\hline 3. & $\begin{array}{l}\text { Kesalahan menuliskan jawaban akhir } \\
\text { Siswa sudah dapat menyelesaikan } \\
\text { permasalahan secara tepat, tetapi tidak } \\
\text { dapat mengekspresikan penyelesaian } \\
\text { tersebut kedalam kalimat matematika yang } \\
\text { diminta oleh soal. }\end{array}$ & $\begin{array}{ll}\text { a. } & \text { Tidak menuliskan } \\
\text { jawaban akhir } \\
\text { b. Menuliskan jawaban } \\
\text { akhir yang tidak sesuai } \\
\text { dengan konteks soal } \\
\text { c. Menuliskan jawaban } \\
\text { akhir namun tidak } \\
\text { sesuai dengan } \\
\text { perhitungan yang } \\
\text { diperoleh } \\
\text { d. Menuliskan jawaban } \\
\text { akhir namun tidak } \\
\text { tepat }\end{array}$ \\
\hline
\end{tabular}

\section{METODE PENELITIAN}

Penelitian ini termasuk dalam penelitian deskriptif dengan pendekatan kualitatif.Hasil dari penelitian ini bersifat deduktif karena data yang diperoleh lebih condong berupa kata-kata dan kalimat dari pada angka-angka.Rancangan penelitian yang digunakan dalam penelitian ini adalah studi kasus. Penelitian ini dimaksudkan untuk mengungkap jenis-jenis kesalahan siswa dilihat dari gaya kognitif siswa materi lingkaran pada siswa kelas VIIIC SMP Negeri 1 Wlingi danfaktor-faktorpenyebabnya.

Sesuai dengan jenis penelitian ini yaitu kualitatif, maka kehadiran peneliti di tempat penelitian diperlukan sebagai komponen utama.Kedudukan peneliti dalam penelitian ini adalah sebagai perencana penelitian, pelaksana penelitian, pengumpul data, dan melaporkan hasil penelitian.Maksud dari perencanaan ialah peneliti membuat rencana yang sudah terjadwal, baik dalam merencanakan kegiatan penelitian maupun pada waktu penelitian berlangsung.Peneliti pengumpul data maksudnya ialah peneliti terjun langsung dalam penelitiansehinggapeneliti mendapatkandatadari sumberdata. 
Data dalam penelitian ini adalah semua informasi yang diperoleh di lapangan yang berkaitan dengan penelitian ini.Data yang diperoleh harus dapat mengungkap kaitan antar sumber informasi. Sedangkan sumber data dari penelitian ini adalah siswa kelas VIII C SMP Negeri 1 Wlingidengan total siswa 20 orang. Dalam menggunakan tes tulis semua siswa dilibatkan.Sedangkan dalam metode wawancara sumber data diambil 4 orang. Pengambilan sumber data ini berdasarkan nilai akhir dari tes dan jenis gaya kognitifyangdimilikiolehsiswa.

Teknik pengumpulan data dalam penelitian ini menggunakan beberapa instrumen,yaitu:

1. Tes tulis

Tes merupakan metode pengumpulan data yang sifatnya mengevaluasi hasil proses belajar. Instrumen dalam penelitian ini berupa sesuatu permasalahan dalam materi lingkaran pada kelas VIII semester genap. Pemberian tes akan dilaksanakan terhadap seluruh siswa kelas VIII C. Tujuan diadakannya tes tersebut adalah untuk mengetahui kesalahan-kesalahan yang dilakukan oleh siswa. Hasil pekerjaan siswa diberi skor kemudian di anaisis untuk mengetahui jenis kesalahan siswa. Selain tes tulis, dalam penelitian ini juga menggunakan Group Embeded Figure Test (GEFT) yang diadopsi dari Witkin et al (1971) untuk membedakan gaya kognitif siswa yaitu Field Independent dan Field Dependent. Witkin et al (dalam Badi, 2012) menyebutkan koefisien reliabilitas tes dari GEFT yaitu 0,82 yang diberikan pada siswa laki-laki dan perempuan. Sehingga pada penelitian ini perlu dilakukan uji validitas maupun reliabilitas.

2. Pedomanwawancara

Wawancara yang dilakukan dalam penelitian ini adalah wawancara terstruktur (dilakukan melalui pertanyaan-pertanyaan yang telah disiapkan sesuai dengan permasalahan yang akan diteliti) dan wawancara tak terstruktur (dilakukan apabila jawaban yang diberikan di luar dari jawaban terstruktur). Dalam penelitian ini wawancara digunakan dalam rangka untuk memperoleh penjelasandaninformasimendalamdari subjekyangditeliti.

3. Dokumentasi

Dokumentasi merupakan pengumpulan data yang menghasilkan catatancatatan penting yang berhubungan dengan masalah yang diteliti, sehingga diperoleh data yang lengkap dan valid bukan berdasarkan dari dugaan semata. Metode ini digunakan untuk mengumpulkan data yang sudah tersedia dalam catatan dokumen seperti daftar nama siswa, data sekolah maupun struktur organisasi sekolah. Fungsi data dari dokumentasi lebih banyak digunakan untuk data pendukung dan pelengkap bagi data yang diperoleh dari tes dan wawancara.

Adapun teknik analisis data dalam penelitian ini menggunakan salah satu teknik analisis data yang dikemukakan oleh Miles dan Huberman (dalam Sugiyono,2011: 337-346)meliputi tigakegiatansebagai berikut:

1. DataReduction(Reduksidata) 
Reduksi data adalah proses penyederhanaan yang dilakukan melalui seleksi, pemfokusan, dan pengabstraksian data mentah menjadi data yang bermakna sesuai dengan tujuan pengamatan. Tahap reduksi data dalam penelitian ini yaitu mengoreksi hasil pekerjaan siswa dengan cara penskoran.

2. DataDisplay(PenyajianData)

Penyajian data adalah proses penampilan data secara lebih sederhana dalam betuk naratif, representasi tabular termasuk dalam format matriks atau grafis. Dalam penyajian ini data berbentuk tabel yaitu berupa rekapitulasi nilai tes siswa dan diskripsi tentang letak kesalahan siswa serta tipe gaya kognitif siswa. Data yang disajikan dalam bentuk uraian singkat yaitu penjelasan dari kesalahan yang dilakukan siswa serta faktorfaktor penyebabnya.Sedangkan data yang disajikan dalam bentuk naratif adalah hasil wawancara terhadap siswa yang dipilih menjadi objek wawancara.

3. Conclusion Drawing(Penyimpulan)

Penyimpulan adalah proses pengambilan intisari dari sajian data yang telah teorganisasi dalam bentuk pernyataan kalimat dan atau formula yang disingkat dan padat tetapi mengandung pengertian yang luas. Pada penelitian ini pengambilan kesimpulan dilakukan dengan cara membandingkan hasil pekerjaan siswa dan hasil wawancara berdasarkan jenis gaya kognitif siswa yang kemudian ditarik kesimpulan letak dan penyebab kesalahan siswa dalam menyelesaikan soal lingkaran.

\section{HASIL PENELITIAN DAN PEMBAHASAN Hasil Penelitian}

Setelah penyusunan instrumen yang berupa masalah matematika topik Lingkaran sebanyak 4 soal dan pedomen wawancara, dilakukan validasi format, isi dan bahasa oleh 3 orang validator. Instrumen dinyatakan valid ( $\mathrm{Va}=2,82 \mathrm{dan}$ 2,78) dan telah direvisi. Selanjutnya dilakukan uji reabilitas untuk instrumen tes di kelas VIIIC SMPN 1 Wlingi, dan dinyatakan reliabel $(\alpha-0,61)$.

Pengambilan data untuk melihat kecendrungan kesalahan siswa, dilakukan terhadap 10 orang siswa kelas VIII C SMPN 1 Wlingi, yang dipilih secara acak.Responden diberikan 4 masalah matematika untuk dikerjakan selama 60 menit, dan dilanjutkan dengan wawancara.Hasil tes menunjukkan semua responden melakukan minimal satu jenis kesalahan.Contoh kesalahan tiap jenis kesalahan adalah sebagai berikut.

1. Kesalahan Transformasi

Siswa dengan kode S01 melakukan kesalahan dalam transformasi soal pada nomor 2 dan 3.Pada soal nomor 2, siswa tidak dapat menjelaskan prosedur yang digunakan dengan tepat meskipun pada lembar jawabannya terlihat jelas prosedur yang digunakannya.Pada soal nomor 2 ini siswa harus dituntun untuk dapat menemukan prosedur yang tepat. Sedangkan untuk soal nomor 3 siswa melakukan kesalahan transformasi yaitu siswa menuliskan cara untuk menentukan hasilnya, namun kurang tepat. Contoh kesalahan transformasi yang dilakukan S01 disajikan dalam Gambar 2. 


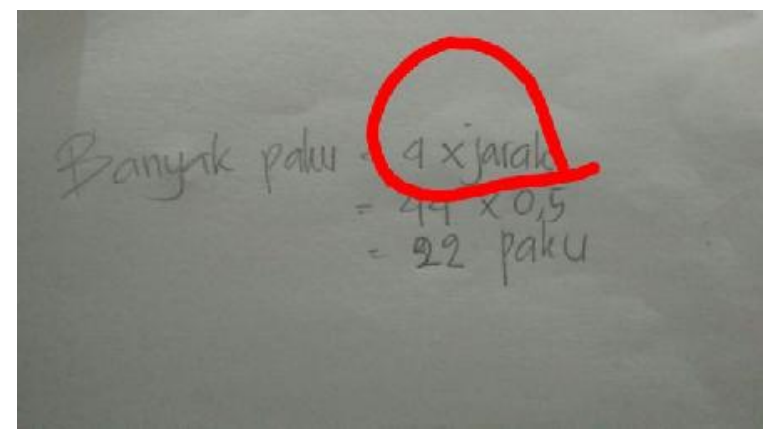

Gambar 2

Catatan : Seharusnya dibagi bukan dikali

Dialog 1.

P1049 : nah kalau sudah dapat keliling terus diapakan buat nyari banyak pakunya?

S0149 : (siswa mencoba mengingat-ingat) dikalikan bu dengan jaraknya P1050 : kok dikalikan?

S0150 Iya bu, kan pakunya makin banyakjadi dikalikan.

Gambar 2 menunjukkan bahwa siswa melakukan kesalahan transformasi yaitu siswa menuliskan cara yang digunakan namun tidak tepat. Seharusnya untuk mencari banyak paku yaitu keliling lingkaran dibagi jarak, bukan 4 dikali jarak. Dari kutipan wawancara juga menunjukkan bahwa siswa tidak dapat menyebutkan cara pengerjaan dengan tepat.

2. Kesalahan keterampilan proses

Siswa dengan kode S01 melakukan kesalahan keterampilan proses pada soal nomor 1, 2, dan 3. Kesalahan keterampilan proses yang dilakukan S01 antara lain kesalahan dalam melakukan komputasi, tidak dapat menjelaskan perhitungan dengan benar, dan tidak menuliskan rumus dengan tepat. Contoh kesalahan keterampilan proses oleh S01 disajikan dalam Gambar 3. Tererlihat bahwa siswa melakukan kesalahan keterampilan proses yaitu siswa salah dalam melakukan komputasi. Hal ini juga terlihat dari kutipan wawancara yang dilakukan, siswa tidak dapat menjelaskan proses perhitungannya

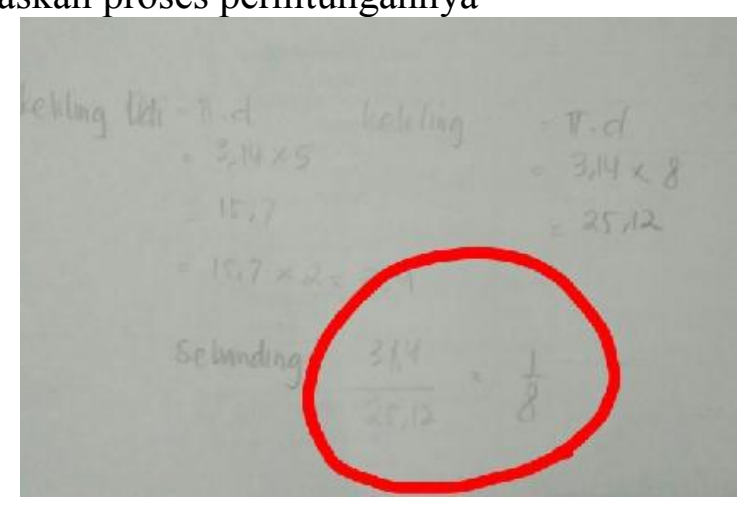


Catatan : seharusnya penyederhanaanya hasilnya bukan $1 / 8$ tapi $5 / 4$

Dialog 2

P1012 : nah, terus kok bisa didapat 1/8?

S01112 : ya diperkecil bu

P1013 :kok bisa 1/8? kamu bagi berapa?

S0113 : ya gak tau bu, hehe ngarang bu

3. Kesalahan penulisan jawaban akhir

Siswa dengan kode S01 melakukan kesalahan penulisan jawaban akhir pada soal nomor 1, 2, 3, dan 4.Kesalahan penulisan jawaban akhir yang dilakukan S01 yaitu tidak menuliskan jawaban akhir, menuliskan jawaban akhir yang tidak sesuai dengan konteks soal, dan menuliskan jawaban akhir namun tidak tepat.Contoh kesalahan penulisan jawaban akhir yang dilakukan S01 disajikan pada Gambar 4.

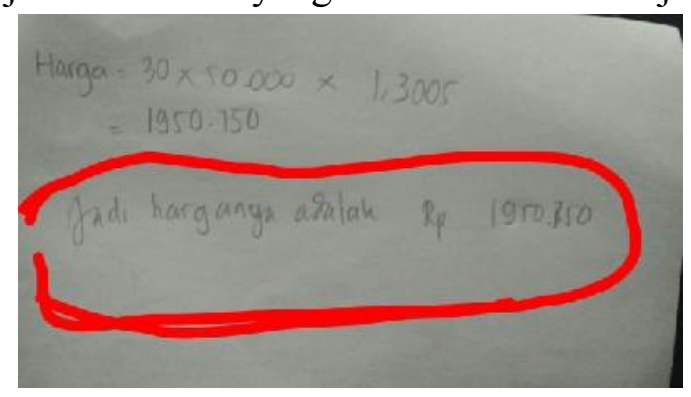

Gambar 4

S0157 : kesimpulannya ya itu bu... Jadi harganya adalah satu juta Sembilan ratus lima puluh ribu selapan ratus lima puluh.

P0112 : yang diminta tadi harga apa biaya penanaman rumput?

S0117 : oh iya bu,, lupa hehe

Gambar 4. Kutipan jawaban dan wawancara S01 soal nomor 4 Gambar 4 menunjukkan bahwa siswa dengan kode S01 melakukan kesalahan penulisan jawaban akhir yaitu siswa menuliskan jawaban akhir yang tidak sesuai dengan konteks soal, seharusnya yang diminta adalah biaya yang dibutuhkan untuk menanam rumput, namun yang dituliskan siswa yaitu harganya.

Dari uraian analisis kesalahan S01, dapat disimpulkan bahwa S01 melakukan kesalahan transformasi, keterampilan proses, dan penulisan jawaban akhir serta jenis kesalahan lain. Namun, S01 cenderung melakukan kesalahan keterampilan proses, dan penulisan jawaban akhir. Kesalahan penulisan jawaban akhir dilakukan pada semua soal, sedangkan kesalahan keterampilan proses dilakukan pada 3 soal. Berdasarkan hasil analisis data dari keenam responden, jenis kesalahan yang dilakukan siswa berdasarkan Kendala kedua atau kesalahan pengolahan matematika dari Analisis Kesalahan Newman yaitu sebagai berikut.

a. Semua responden kecuali S05 melakukan semua jenis kesalahan. 
b. S01, S04 dan S05 cenderung melakukan kesalahan keterampilan proses, dan penulisan jawaban akhir;

c. S02 dan S06 cenderung melakukan kesalahan transformasi, keterampilan proses, dan penulisan jawaban akhir;

d. S03 cenderung melakukan semua jenis kesalahan termasuk jenis kesalahan newman lainnya. Berikut ini rekapitulasi banyaknya kesalahan yang dilakukan oleh responden untuk tiap jenis kesalahan

Tabel 2. Klasifikasi Jenis Kesalahan Responden

\begin{tabular}{|c|c|c|c|c|c|}
\hline \multirow[t]{2}{*}{ Subjek ke } & \multicolumn{3}{|c|}{ Jenis Kesalahan Pengolahan Data } & \multirow{2}{*}{$\begin{array}{c}\text { Jenis } \\
\text { Kesalahan } \\
\text { Lainnya }\end{array}$} & \multirow[t]{2}{*}{ Jumlah } \\
\hline & Transformasi & $\begin{array}{c}\text { Ketrampilan } \\
\text { Proses } \\
\end{array}$ & $\begin{array}{c}\text { Penulisan } \\
\text { Jawaban Akhir }\end{array}$ & & \\
\hline 1 & 2 & 3 & 4 & 6 & 15 \\
\hline 2 & 3 & 3 & 4 & 5 & 15 \\
\hline 3 & 1 & 2 & 2 & 8 & 13 \\
\hline 4 & 1 & 3 & 3 & 5 & 12 \\
\hline 5 & 0 & 3 & 4 & 4 & 11 \\
\hline 6 & 3 & 4 & 4 & 3 & 14 \\
\hline Jumlah & 10 & 18 & 21 & 31 & 80 \\
\hline Persentase & 12,5 & 22,5 & 26,25 & 38,75 & 100 \\
\hline
\end{tabular}

Dapat dilihat bahwa jenis kesalahan pengolahan matematika sebesar $61,25 \%$ lebih besar daripada jenis kesalahan lain yaitu sebesar 38,75\%. Kecendrungan kesalahan terbesar terjadi pada jenis kesalahan jawaban akhir dan ketrampilan proses. Sedangkan kesalahan transformasi relatif lebih kecil, bahkan ada seorang responden yang tidak melakukan kesalahan jenis ini.

\section{SIMPULAN DAN SARAN}

\section{Simpulan}

Berdasarkan hasil analisis data dan pembahasan, dapat diambil kesimpulan tentang jenis kesalahan yang dilakukan siswa berdasarkan Kendala kedua dari Analisis Kesalahan Newman yaitu sebagai berikut, jenis kesalahan pengolahan matematika sebesar $61,25 \%$ lebih besar daripada jenis kesalahan lain yaitu sebesar $38,75 \%$. Kecendrungan kesalahan terbesar terjadi pada jenis kesalahan jawaban akhir dan ketrampilan proses. Sedangkan kesalahan transformasi relatif lebih kecil, bahkan ada seorang responden yang tidak melakukan kesalahan jenis ini

\section{Saran}

Saran yang dapat disampaikan adalah pemberian soal cerita atau masalah matematika di sekolah harus lebih sering, untuk mengasah kemampuan siswa dan mengurangi kesalahan yang dilakukan siswa. 


\section{DAFTAR PUSTAKA}

Apriliawan. (2015). Analisis Kesalahan Penyelesaian Soal Uraian Matematika Siswa MTs pada Pokok Bahasan Unsur-Unsur Lingkaran.Dalam Jurmal Ilmiah Pendidikan Matematika IKIP PGRI Madiun.Vol 1. No 2. [Online]. Tersedia: http://ejournal.ikip pgrimadiun.ac.id/index.php/ JIPM/article/view/277.

Ardiyanti. (2014). Analisis Kesalahan Siswa dalam Menyelesaikan Soal Cerita Matematika. Dalam Jurnal Pendidikan Matematika UNILA. Vol 7. No 4[Online].Tersedia:http://jurnal.fkip.unila.ac.id/index.php/MTK/article/vie $\mathrm{w} / 6590$.

Hidayat. (2013). Analisis Kesalahan Siswa dalam Menyelesaikan Soal pada Materi Ruang Dimensi Tiga Ditinjau dari Gaya Kognitif Siswa. Dalam Jurnal Pendidikan Matematika. Vol 1 . No 1. [Online].Tersedia:http://jurnal.fkip.uns.ac.id/index.php/ matematika/article/view/1460.[ 30 Juli 2015].

Subaidah, Siti. 2010. Kemampuan Siswa SMP kelas VIII di Kota Malang dalam Menyelesaikan Soal Cerita Matematika Ditinjau dari Tahapan Analisis Kesalahan Newman.Malang : Skripsi tidak diterbitkan 